\title{
Automation Diagnosis of Skin Disease in Humans using Dempster-Shafer Method
}

\author{
Dyna Marisa Khairina ${ }^{1, *}$, Heliza Rahmania Hatta $^{1}$, Rustam Rustam $^{1}$, and Septya Maharani ${ }^{1}$ \\ ${ }^{1}$ Department of Computer Science, Faculty of Computer Science and Information Technology, Mulawarman University, Samarinda - \\ Indonesia
}

\begin{abstract}
Skin disease is an infectious disease that is common in people of all ages. Disorders of the skin often occur because there are factors, among others, are climate, environment, shelter, unhealthy living habits, allergies and others. Skin diseases in Indonesia are mostly caused by bacterial, fungal, parasitic, and allergies. The objective of the research is to diagnose skin diseases in humans by using the method of making decision tree then performing the search by forward chaining and calculating the probability value of Dempster-Shafer method. The results of research in the form of an automated system that can resemble an expert in diagnosing skin disease accurately and can help in overcoming the problem of skin diseases.
\end{abstract}

\section{Introduction}

The skin is the organ that lies outside and limits it from the human environment. The skin is an essential and vital organ and is a mirror of health and life. The skin is also very complex, elastic and sensitive, varying in climatic conditions, age, gender, race and also highly dependent on the location of the body [1].

Skin diseases in Indonesia are mostly caused by bacterial infections, fungi, parasites, and allergic basic diseases. This is different from Western countries that are more influenced by degenerative factors. Besides the difference in causes, other factors such as climate, habits and the environment also contributed to differences in clinical images of skin diseases [2].

Epidemiology data show that superficial dermatomycosis is a skin disease common in all societies, both rural and urban, not only in developing countries but also in developed countries. Although the disease is not fatal, but because it is often chronic, and not a few are resistant to anti-fungal drugs, the disease can cause disruption of comfort and reduce quality of life for the sufferer [3].

The Dempster-Shafer method is the representation, combination and propagation of uncertainty, in which this theory has some characteristics that are institutive in accordance with the way an expert thinks, but is based on a strong mathematical [4].

\section{Uncertainties in Expert System}

The construction of expert and other intelligent computer systems requires to be sophisticated mechanism for representing and reasoning with uncertain information. At least three forms of uncertainty can be identified as playing a significant role in these types of systems. The first of these possibility and uncertainty appears in situations where the value of a variable can only be narrowed down to a set of values one of which is the actual value of the variable. The second kind of uncertainty is related to situations in which there exists uncertainty as to satisfaction of a predicate by an element. This is manifested by concepts which have imprecise or gray boundaries. A very powerful tool for handling this type of uncertainty which also handles the first type of uncertainty is the fuzzy set. The third type of uncertainty is related to situations in which the value of a variable assumes can be modeled by the performance of a random experiment. [5]

\section{Dempster-Shafer Method}

The Dempster-Shafer method was first introduced by Dempster [6], which attempts to model the uncertainty with range probabilities rather than as a single probability. Then in 1976 Shafer published the Dempster theory in a book called Mathematical Theory Of Evident [7]. Dempster-Sahfer Theory of Evidence, suggests a way to give the weight of confidence according to the facts collected. In theory it can distinguish uncertainty and ignorance. The Dempster-Shafer Theory is a representation, combination and propagation of uncertainty, in which this theory has some characteristics that are institutive in accordance with the way an expert thinks, but a strong mathematical basis [4].

In general Dempster-Shafer theory is written in an interval: [Belief, Plausibility]. Belief (Bel) is a measure of the strength of evidence in favor of a set of propositions. If the value of 0 then indicates that there is no evidence, and if the value of 1 indicates a certainty. Plausibility (Pls) will reduce the level of certainty of the evidence. Plausibility is 0 to 1 . If it is sure of $X^{\prime}$, then it 
can be said that Bell $\left(\mathrm{X}^{\prime}\right)=1$, so the above formula values from Pls $(\mathrm{X})=0$.

According to Giarratano and Riley the Belief function can be formulated and shown in the equation:

$$
\operatorname{Bel}(X)=\sum_{\mathrm{Y} \subseteq \mathrm{X}} m(Y)
$$

And Plausibility is denoted in the equation:

$$
P l s(X)=1-\operatorname{Bel}(X)=1-\sum m(X)
$$

Where:

$$
\begin{array}{ll}
\text { Bel }(X) & \text { : Belief }(X) \\
\text { Pls (X) } & \text { : Plausibility }(X) \\
\mathrm{m}(X) & \text { : Mass function from (X) } \\
\mathrm{m}(\mathrm{Y}) & \text { : Mass function from (Y) }
\end{array}
$$

The Dempster-Shafer theory states the existence of a frame of discrement denoted by a symbol $(\theta)$. Frame of discrement is the universe of speech of a set of hypotheses so often called the environment shown simultaneously: $\theta=\{01,02, \ldots 0 \mathrm{~N}\}$

Where:

$\begin{array}{ll}\theta & : \text { Frame of discernment } \\ 01,02, \ldots 0 \mathrm{~N} & : \text { Elements in the environment }\end{array}$

The environment contains elements that describe the possibility of an answer, and there is only one that will correspond to the required answer. This possibility in Dempster-Shafer theory is called the power set and denoted by $P(\theta)$, each element in this power set has an interval value of 0 to 1 .

$\mathrm{m}: \mathrm{P}(\theta) \rightarrow[0,1]$

So it can be formulated in equations with:

$\sum m(X)=1$

$\mathrm{X} \in \mathrm{P}(\theta)$

Where:

$\mathrm{P}(\theta) \quad$ : Power set

$\mathrm{m}(\mathrm{X}) \quad$ : Mass function $(\mathrm{X})$

The mass function (m) in Dempster-shafer theory is the degree of confidence of an evidence, often called an evidence measure so that it is denoted by $(\mathrm{m})$. The goal is to relate the trust size of the elements $\theta$. Not all evidences directly support each element. For that we need probability density function $(\mathrm{m})$. The $\mathrm{m}$ value not only defines the elements $\theta$ only, but also all the subset. So if $\theta$ contains $n$ elements, then the subset $\theta$ is $2 \mathrm{n}$. The number of sems in a subset $\theta$ equals 1 . If there is no information whatsoever to select the hypothesis, then the value: $\operatorname{m}\{\theta\}=1,0$

If $\mathrm{X}$ is a subset of $\theta$, with $\mathrm{m} 1$ as its density function, and $\mathrm{Y}$ is also a subset of $\theta$ with $\mathrm{m} 2$ as its density function, a function of combinations $\mathrm{m} 1$ and $\mathrm{m} 2$ as $\mathrm{m} 3$ can be formed as shown in equation:

$$
\mathrm{m}_{3}(\mathrm{Z})=\frac{\sum_{\mathrm{X} \cap \mathrm{Y}=\mathrm{Z}} \mathrm{m}_{1}(\mathrm{X}) \cdot \mathrm{m}_{2}(\mathrm{Y})}{1-\sum_{\mathrm{X} \cap \mathrm{Y}=\emptyset} \mathrm{m}_{1}(\mathrm{X}) \cdot \mathrm{m}_{2}(\mathrm{Y})}
$$

Where:

$\mathrm{m}_{3}(\mathrm{Z}) \quad$ : mass function from evidence $(\mathrm{Z})$

$\mathrm{m}_{1}(\mathrm{X}) \quad$ : mass function from evidence $(\mathrm{X})$, which is obtained from the confidence value of an evidence multiplied by the disbelief value of the evidence.

$\mathrm{m}_{2}(\mathrm{Y}) \quad$ : mass function from evidence $(\mathrm{Y})$, which is obtained from the confidence value of an evidence multiplied by the disbelief value of the evidence.

$\sum \mathrm{X} \cap \mathrm{Y}=\mathrm{Z} \mathrm{m}_{1}(\mathrm{X}) \cdot \mathrm{m}_{2}(\mathrm{Y})$ : is a strength value from the evidence $Z$ obtained from a combination of confidence values set of evidence.

\section{Research Method}

\subsection{Knowledge Acquisition}

Initial identification process to obtain initial data and understanding for specific determination of the problem then conducted an interview with a skin specialist. Preliminary data and understanding obtained data of symptoms and illness then illustrated in a decision tree diagram. In the decision tree diagram of the skin disease diagnosis expert system, the symptoms are grouped and denoted by a combination of numeric and letter codes, then disease (diagnosis) and handling (solution) are denoted by numeric and letter codes. The decision tree is illustrated in Figure 1.

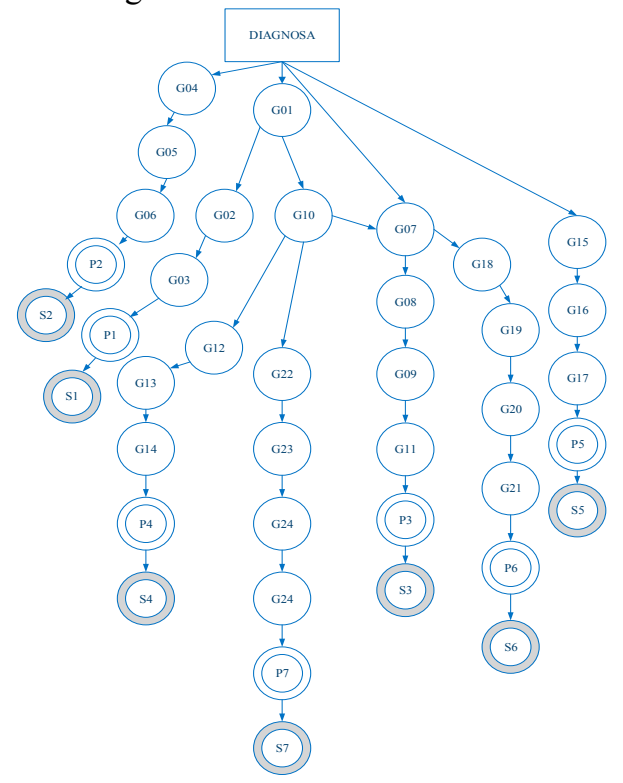

Fig.1. Decision Tree for Diagnosis of Skin Disease in Humans

Table 1 and Table 2 show the symptoms and illnesses of the decision tree in Figure 1. 
Table 1. Description of the Symptom Code

\begin{tabular}{|c|c|}
\hline Code & Symptoms \\
\hline G01 & Reddish patches on the skin \\
\hline G02 & $\begin{array}{l}\text { The presence of plaques (skin lesions whose surface is } \\
\text { elevated and flat top) }\end{array}$ \\
\hline G03 & $\begin{array}{l}\text { Symptoms occur koebner phenomenon (skin disorder, } \\
\text { where if healthy skin exposed to trauma / scratched, } \\
\text { healthy skin will also be a disorder) }\end{array}$ \\
\hline G04 & $\begin{array}{l}\text { The presence of a papula (solid protrusion bordered on } \\
\text { a skin surface of }<1 \mathrm{~cm} \text { in diameter) of a small needle- } \\
\text { sized head }\end{array}$ \\
\hline G05 & Papula grows prominent \\
\hline G06 & $\begin{array}{l}\text { The surface of the skin becomes darker and } \\
\text { hyperkeratosis (the skin becomes thick rough) }\end{array}$ \\
\hline G07 & Fever \\
\hline G08 & $\begin{array}{l}\text { Rashes appear that become small bumps then turn into } \\
\text { nodules with fluid }\end{array}$ \\
\hline G09 & Limp \\
\hline G10 & Itchy \\
\hline G11 & Appetite is gone \\
\hline G12 & The skin feels dry \\
\hline G13 & Skin thickened \\
\hline G14 & Skin scab \\
\hline G15 & $\begin{array}{l}\text { The presence of macula hipopigmentasi (skin disorder } \\
\text { where the white color is not rising flat compared to } \\
\text { surrounding healthy skin) on the asymptomatic skin }\end{array}$ \\
\hline G16 & $\begin{array}{l}\text { The appearance of white fine spots on the skin is not } \\
\text { scaly }\end{array}$ \\
\hline G17 & Skin looks white and slippery \\
\hline G18 & Shivering \\
\hline G19 & Out of breath \\
\hline G20 & Pain or joint joints in one part of the body \\
\hline G21 & $\begin{array}{l}\text { The appearance of reddish spots on the skin that } \\
\text { eventually form a bubble of liquid }\end{array}$ \\
\hline G22 & Skin blisters \\
\hline G23 & Appears a red bump on the itchy part \\
\hline G24 & Itching is more intense especially at night \\
\hline G25 & $\begin{array}{l}\text { Thickening and wrinkles on the skin are covered by } \\
\text { yellowish-gray crust }\end{array}$ \\
\hline
\end{tabular}

Table 2. Decription of the Disease Code

\begin{tabular}{cll}
\hline Code & & Disease \\
\hline P1 & Psoriasis & \\
P2 & Verruca \\
P3 & Varicella & \\
P4 & Eczema \\
P5 & Vitiligo \\
P6 & Herpes & \\
P7 & Scabies & \\
\hline
\end{tabular}

\subsection{Knowledge Base}

After the acquisition of knowledge then afterwards done representation of knowledge by making model of rule.

a. For example, for the first rule (R01) is:

IF G1

AND G2

AND G3

THEN Psoriasis

with the weighting value of each of the following symptoms:

$$
\begin{aligned}
\mathrm{G} 01 & =0.5=\mathrm{P} 1 \text { and } \mathrm{P} 4 \\
\mathrm{G} 02 & =0.8=\mathrm{P} 1 \\
\mathrm{G} 03 & =0.8=\mathrm{P} 1
\end{aligned}
$$

from the value of the symptom weights above, then determined initial density $(\mathrm{m})$ value consisting of belief and plausibility.
Symptom 1: Reddish spots on the skin, then obtained : $\mathrm{m}_{1}\{\mathrm{P} 1, \mathrm{P} 4\}=0.5$

The plausibility value of the formula is then determined $P l=1-B e l$

$\mathrm{m}_{1}\{\mathrm{P} 1, \mathrm{P} 4\}=1-0.5=0.5$

Symptom 2: The presence of a plaque (skin lesions that surface is raised and flat top), then obtained: $\mathrm{m}_{1}\{\mathrm{P} 1\}=$ 0.8

The plausibility value of the formula is then determined $P l=1-B e l$ $\mathrm{m}_{1}\{\mathrm{P} 1\}=1-0.8=0.2$

Based on the initial density determination on symptoms 1 and 2, the initial density of the next

\begin{tabular}{|c|c|c|c|c|}
\hline \multirow{2}{*}{ No } & \multirow{2}{*}{ Symptoms } & \multirow{2}{*}{ Disease } & \multicolumn{2}{|c|}{ Density (m) } \\
\hline & & & Belief & Plausibility \\
\hline 1 & $\begin{array}{l}\text { Reddish patches on } \\
\text { the skin }\end{array}$ & $\mathrm{P} 1, \mathrm{P} 4$ & 0.5 & 0.5 \\
\hline 2 & $\begin{array}{l}\text { The presence of } \\
\text { plaques (skin lesions } \\
\text { whose surface is } \\
\text { elevated and flat top) }\end{array}$ & $\mathrm{P} 1$ & 0.8 & 0.2 \\
\hline 3 & $\begin{array}{l}\text { Symptoms occur } \\
\text { koebner phenomenon } \\
\text { (skin disorder, where } \\
\text { if healthy skin } \\
\text { exposed to trauma / } \\
\text { scratched, healthy } \\
\text { skin will also be a } \\
\text { disorder) }\end{array}$ & $\mathrm{P} 1$ & 0.8 & 0.2 \\
\hline
\end{tabular}
symptoms can be seen in Table 3 .

Table 3. Determination of Initial Density (m)

From Table 3 we can calculate the new density (m) value by creating a combination rule table first. Then the resulting combination will be used when indicating a new symptom.

Table 4. Combination Rule for $\mathrm{m}_{3}$

\begin{tabular}{|c|c|c|}
\hline Density 1 & $\mathrm{~m}_{2}\{\mathrm{P} 1\} 0,8$ & $\mathrm{~m}_{2}\{\theta\} 0.2$ \\
\hline $\mathrm{m}_{1}\{\mathrm{P} 1, \mathrm{P} 4\} 0.5$ & $\{\mathrm{P} 1\} 0.4$ & $\{\mathrm{P} 1, \mathrm{P} 4\} 0.1$ \\
\hline $\mathrm{m}_{1}\{\theta\} 0.5$ & $\{\mathrm{P} 1\} 0.4$ & $\{\theta\} 0.1$ \\
\hline
\end{tabular}

Then calculated :

a) $\mathrm{m}_{3}\{\mathrm{P} 1\}=\frac{0.4+0.4}{1-0}=0.8$

b) $\mathrm{m}_{3}\{\mathrm{P} 1, \mathrm{P} 4\}=\frac{0.1}{1-0}=0.1$

c) $\mathrm{m}_{3}\{\theta\}=\frac{0.1}{1-0}=0.1$

Symptom 3: Symptoms of koebner phenomenon (skin disorder, where if healthy skin is affected by trauma / scratches, healthy skin will also be a disorder).

Based on the decision tree and the density value of the symptoms of the disease it is obtained: $\mathrm{m}_{4}\{\mathrm{P} 1\}=0,8$ Then plausibility value: $\mathrm{m}_{4}\{\theta\}=0,2$ 
Table 5. Combination Rule for $\mathrm{m}_{5}$

\begin{tabular}{|c|c|c|}
\hline Density 3 & $\mathrm{~m}_{4}\{\mathrm{P} 1\} 0,8$ & $\mathrm{~m}_{4}\{\theta\} 0,2$ \\
\hline $\mathrm{m}_{3}\{\mathrm{P} 1\} 0.8$ & $\{\mathrm{P} 1\} 0.64$ & $\{\mathrm{P} 1\} 0.16$ \\
\hline $\mathrm{m}_{3}\{\mathrm{P} 1, \mathrm{P} 4\} 0.1$ & $\{\mathrm{P} 1\} 0.08$ & $\{\mathrm{P} 1, \mathrm{P} 4\} 0.02$ \\
\hline $\mathrm{m}_{3}\{\theta\} 0.1$ & $\{\mathrm{P} 1\} 0.08$ & $\{\theta\} 0.02$ \\
\hline
\end{tabular}

Then calculated :

a) $\mathrm{m}_{5}\{\mathrm{P} 1\}=\frac{0.64+0.16+0.08+0.08}{1-0}=0.96$

b) $\mathrm{m}_{5}\{\mathrm{P} 1, \mathrm{P} 4\}=\frac{0.02}{1-0}=0.02$

c) $\mathrm{m}_{5}\{\theta\}=\frac{0.02}{1-0}=0.02$

Then the magnitude of the possibility of users affected by Psoriasis disease is $96 \%$.

b. For example, the rule for the second rule (R02) is:

IF G1

AND G10

AND G12

AND G13

AND G14

THEN Eczema

with the weighting value of each of the following symptoms:

$$
\begin{aligned}
& \mathrm{G} 01=0,5=\mathrm{P} 1 \text { and } \mathrm{P} 4 \\
& \mathrm{G} 10=0,5=\mathrm{P} 3, \mathrm{P} 4 \text { and } \mathrm{P} 7 \\
& \mathrm{G} 12=0,7=\mathrm{P} 4 \\
& \mathrm{G} 13=0,6=\mathrm{P} 4 \\
& \mathrm{G} 14=0,6=\mathrm{P} 4
\end{aligned}
$$

from the value of the symptom weights above, then determined initial density (m) value consisting of belief and plausibility.

Symptom 1: Reddish patches on the skin, then obtained: $\mathrm{m}_{1}\{\mathrm{P} 1, \mathrm{P} 4\}=0.5$

The plausibility value of the formula is then determined $P l=1-B e l$

$\mathrm{m}_{1}\{\mathrm{P} 1, \mathrm{P} 4\}=1-0.5=0.5$

Symptom 10: Itchy, then obtained: $\mathrm{m}_{1}\{\mathrm{P} 3, \mathrm{P} 4, \mathrm{P} 7\}=0.5$ The plausibility value of the formula is then determined $P l=1-B e l$

$\mathrm{m}_{1}\{\mathrm{P} 1\}=1-0.5=0.5$

Table 6. Determination of Initial Density (m)

\begin{tabular}{clccc}
\hline \multirow{2}{*}{ No } & Symptoms & Disease & \multicolumn{2}{c}{ Density (m) } \\
& \multicolumn{1}{c}{ Belief } & Plausibility \\
\hline 1 & Reddish & P1, P4 & 0.5 & 0.5 \\
& $\begin{array}{l}\text { patches on the } \\
\text { skin }\end{array}$ & P3, P4, P7 & 0.5 & \\
2 & Itchy & P4 & 0.7 & 0.5 \\
3 & The skin feels & & & 0.3 \\
& dry & P4 & 0.6 & 0.4 \\
4 & Skin thickened & P4 & 0.6 & 0.4 \\
5 & Skin scab & & & \\
\hline
\end{tabular}

Based on the initial density determination on symptoms 1 and 10, the initial density of the next symptoms can be seen in Table 6 .
From Table 6 we can calculate the new density (m) value by creating a combination rule table first. Then the resulting combination will be used when indicating a new symptom.

Table 7. Combination Rule for $\mathrm{m}_{3}$

\begin{tabular}{|c|c|c|}
\hline Density $\mathrm{P}$ & $\mathrm{m}_{2}\{\mathrm{P} 3, \mathrm{P} 4, \mathrm{P} 7\} 0.5$ & $\mathrm{~m}_{2}\{\theta\} 0.5$ \\
\hline $\mathrm{m}_{1}\{\mathrm{P} 1, \mathrm{P} 4\} 0.5$ & $\{\mathrm{P} 4\} 0.25$ & $\{\mathrm{P} 1, \mathrm{P} 4\} 0.25$ \\
\hline $\mathrm{m}_{1}\{\theta\} 0.5$ & $\{\mathrm{P} 3, \mathrm{P} 4, \mathrm{P} 7\} 0.25$ & $\{\theta\} 0.25$ \\
\hline
\end{tabular}

Then calculated :

a) $\mathrm{m}_{3}\{\mathrm{P} 4\}=\frac{0.25}{1-0}=0.25$

b) $\mathrm{m}_{3}\{\mathrm{P} 1, \mathrm{P} 4\}=\frac{0.25}{1-0}=0.25$

c) $\mathrm{m}_{3}\{\mathrm{P} 3, \mathrm{P} 4, \mathrm{P} 7\}=\frac{0.25}{1-0}=0.25$

d) $\mathrm{m}_{3}\{\theta\}=\frac{0.25}{1-0}=0.25$

Symptom 12: The skin feels dry

\begin{tabular}{|c|c|c|}
\hline $\begin{array}{ll} & \text { Density } 4 \\
\text { Density } 3 & \end{array}$ & $\mathrm{~m}_{4}\{\mathrm{P} 4\} 0,7$ & $\mathrm{~m}_{4}\{\theta\} 0,3$ \\
\hline $\mathrm{m}_{3}\{\mathrm{P} 4\} 0,25$ & $\{\mathrm{P} 4\} 0,175$ & $\{\mathrm{P} 4\} 0,075$ \\
\hline $\mathrm{m}_{3}\{\mathrm{P} 1, \mathrm{P} 4\} \quad 0,25$ & $\{\mathrm{P} 4\} 0,175$ & $\{\mathrm{P} 1, \mathrm{P} 4\} 0,075$ \\
\hline $\mathrm{m}_{3}\{\mathrm{P} 3, \mathrm{P} 4, \mathrm{P} 7\} \quad 0,25$ & $\{\mathrm{P} 4\} 0,175$ & $\mathrm{~m}_{3}\{\mathrm{P} 3, \mathrm{P} 4, \mathrm{P} 7\} 0,075$ \\
\hline $\mathrm{m}_{3}\{\theta\} 0,25$ & $\{\mathrm{P} 4\} 0,175$ & $\{\theta\} 0,075$ \\
\hline
\end{tabular}

Based on the decision tree and the density value of the symptoms of the disease it is obtained: $\mathrm{m}_{4}\{\mathrm{P} 4\}=0,7$ Then plausibility value: $\mathrm{m}_{4}\{\theta\}=0,3$

Table 8. Combination Rule for $\mathrm{m}_{5}$

Then calculated:

a. $\mathrm{m}_{5}\{\mathrm{P} 4\}=\frac{0.175+0.175+0.175+0.175+0.175}{1-0}=0.775$

b. $\mathrm{m}_{5}\{\mathrm{P} 1, \mathrm{P} 4\}=\frac{0.075}{1-0}=0.075$

c. $\mathrm{m}_{5}\{\mathrm{P} 3, \mathrm{P} 4, \mathrm{P} 7\}=\frac{0.075}{1-0}=0.075$

d. $\mathrm{m}_{5}\{\theta\}=\frac{0.075}{1-0}=0.075$

Symptom 13: Skin thickened

Based on the decision tree and the density value of the symptoms of the disease it is obtained: $\mathrm{m}_{6}\{\mathrm{P} 4\}=0,6$ Then plausibility value: $\mathrm{m}_{6}\{\theta\}=0,4$

Table 9. Combination Rule for $\mathrm{m}_{5}$

\begin{tabular}{|l|c|c|}
\hline Density 5 Density 6 & $\mathrm{m}_{6}\{\mathrm{P} 4\} 0,6$ & $\mathrm{~m}_{6}\{\theta\} 0,4$ \\
\hline $\mathrm{m}_{5}\{\mathrm{P} 4\} 0,775$ & $\{\mathrm{P} 4\} 0,465$ & $\{\mathrm{P} 1\} 0,31$ \\
\hline $\mathrm{m}_{5}\{\mathrm{P} 1, \mathrm{P} 4\} 0,075$ & $\{\mathrm{P} 4\} 0,045$ & $\{\mathrm{P} 1, \mathrm{P} 4\} 0,03$ \\
\hline $\mathrm{m}_{5}\{\mathrm{P} 3, \mathrm{P} 4, \mathrm{P} 7\} 0,075$ & $\{\mathrm{P} 4\} 0,045$ & $\{\mathrm{P} 3, \mathrm{P} 4, \mathrm{P} 7\} 0,03$ \\
\hline $\mathrm{m}_{5}\{\theta\} 0,075$ & $\{\mathrm{P} 4\} 0,045$ & $\{\theta\} 0,03$ \\
\hline
\end{tabular}

Then calculated:

a. $\quad \mathrm{m}_{7}\{\mathrm{P} 4\}=\frac{0.465+0.045+0.045+0.045+0.031}{1-0}=0.91$

b. $\mathrm{m}_{7}\{\mathrm{P} 1, \mathrm{P} 4\}=\frac{0.03}{1-0}=0.03$ 

c. $\mathrm{m}_{7}\{\mathrm{P} 3, \mathrm{P} 4, \mathrm{P} 7\}=\frac{0.03}{1-0}=0.03$
d. $\mathrm{m}_{7}\{\theta\}=\frac{0.03}{1-0}=0.03$

\section{Symptom 14: Skin scab}

Based on the decision tree and the density value of the symptoms of the disease it is obtained: $\mathrm{m}_{8}\{\mathrm{P} 4\}=0,6$ Then plausibility value: $\mathrm{m}_{8}\{\theta\}=0,4$

Table 10. Combination Rule for $\mathrm{m}_{5}$

\begin{tabular}{|l|c|c|}
\hline Density 7 & $\mathrm{M}_{8}\{\mathrm{P} 4\} 0,6$ & $\mathrm{~m}_{8}\{\theta\} 0,4$ \\
\hline $\mathrm{m}_{7}\{\mathrm{P} 4\} 0,91$ & $\{\mathrm{P} 4\} 0,546$ & $\{\mathrm{P} 4\} 0,364$ \\
\hline $\mathrm{m}_{7}\{\mathrm{P} 1, \mathrm{P} 4\} 0,03$ & $\{\mathrm{P} 4\} 0,018$ & $\{\mathrm{P} 1, \mathrm{P} 4\} 0,012$ \\
\hline $\mathrm{m}_{7}\{\mathrm{P} 3, \mathrm{P} 4, \mathrm{P} 7\} 0,03$ & $\{\mathrm{P} 4\} 0,018$ & $\{\mathrm{P} 3, \mathrm{P} 4, \mathrm{P} 7\} 0,012$ \\
\hline $\mathrm{m}_{7}\{\theta\} 0,03$ & $\{\mathrm{P} 4\} 0,018$ & $\{\theta\} 0,012$ \\
\hline
\end{tabular}

Then calculated:

a. $\mathrm{m}_{9}\{\mathrm{P} 4\}=\underline{0.546+0.0364+0.018+0.018+0.18}=0.964$ b. $\mathrm{m}_{9}\{\mathrm{P} 1, \mathrm{P} 4\}=\frac{0.012}{1-0}=0.012$

c. $\mathrm{m}_{9}\{\mathrm{P} 3, \mathrm{P} 4, \mathrm{P} 7\}=\frac{0.012}{1-0}=0.012$

d. $\mathrm{m}_{9}\{\theta\}=\frac{0.012}{1-0}=0.012$

Then the magnitude of the possibility of users affected by Eczema disease is $96 \%$.

\section{Results and Discussion}

This system aims to create a model system that can effectively diagnose skin diseases automatically and work like an expert. Measurement of effectiveness is done by testing the accuracy of diagnostic results by using 20 data samples. Table 11 shows detailed diagnostic accuracy test data.

Table 11. Testing Accuracy of Diagnostic Results

\begin{tabular}{|c|c|c|c|c|c|}
\hline No & & Symptoms Suffered & $\begin{array}{c}\text { System } \\
\text { Diagnostic } \\
\text { Results }\end{array}$ & $\begin{array}{c}\text { Expert } \\
\text { Diagnosis } \\
\text { Results }\end{array}$ & $\begin{array}{l}\text { Accuracy } \\
\text { of } \\
\text { Comparis } \\
\text { on } \\
\text { Results }\end{array}$ \\
\hline 1 & $\begin{array}{l}\text { G08 } \\
\text { G12 } \\
\text { G17 } \\
\text { G20 } \\
\text { G21 }\end{array}$ & $\begin{array}{l}\text { Rashes appear that become small bumps then turn into nodules with fluid } \\
\text { The skin feels dry } \\
\text { Skin looks white and slippery } \\
\text { Pain or joint joints in one part of the body } \\
\text { The appearance of reddish spots on the skin that eventually form a bubble of liquid }\end{array}$ & Herpes & Herpes & Suitable \\
\hline 2 & $\begin{array}{l}\text { G01 } \\
\text { G04 } \\
\text { G07 } \\
\text { G10 } \\
\text { G13 }\end{array}$ & $\begin{array}{l}\text { Reddish patches on the skin } \\
\text { The presence of a papula (solid protrusion bordered on a skin surface of }<1 \mathrm{~cm} \text { in } \\
\text { diameter) of a small needle-sized head } \\
\text { Fever } \\
\text { Itchy } \\
\text { Skin thickened }\end{array}$ & Eczema & Eczema & Suitable \\
\hline 3 & $\begin{array}{l}\text { G02 } \\
\text { G03 } \\
\text { G04 } \\
\text { G05 }\end{array}$ & $\begin{array}{l}\text { The presence of plaques (skin lesions whose surface is elevated and flat top) } \\
\text { Symptoms occur koebner phenomenon (skin disorder, where if healthy skin exposed } \\
\text { to trauma / scratched, healthy skin will also be a disorder) } \\
\text { The presence of a papula (solid protrusion bordered on a skin surface of }<1 \mathrm{~cm} \text { in } \\
\text { diameter) of a small needle-sized head } \\
\text { Papula grows prominent }\end{array}$ & Psoriasis & Veruca & $\begin{array}{c}\text { Not } \\
\text { Suitable }\end{array}$ \\
\hline 4 & $\begin{array}{l}\text { G06 } \\
\text { G08 } \\
\text { G09 } \\
\text { G15 }\end{array}$ & $\begin{array}{l}\text { The surface of the skin becomes darker and hyperkeratosis (the skin becomes thick } \\
\text { rough) } \\
\text { Rashes appear that become small bumps then turn into nodules with fluid } \\
\text { Limp } \\
\text { The presence of macula hipopigmentasi (skin disorder where the white color is not } \\
\text { rising flat compared to surrounding healthy skin) on the asymptomatic skin }\end{array}$ & Varicella & Varicella & Suitable \\
\hline 5 & $\begin{array}{l}\text { G09 } \\
\text { G10 } \\
\text { G11 } \\
\text { G19 } \\
\text { G20 }\end{array}$ & $\begin{array}{l}\text { Limp } \\
\text { Itchy } \\
\text { Appetite is gone } \\
\text { Out of breath } \\
\text { Pain or joint joints in one part of the body }\end{array}$ & Varicella & Varicella & Suitable \\
\hline 6 & $\begin{array}{l}\text { G10 } \\
\text { G13 } \\
\end{array}$ & $\begin{array}{l}\text { The presence of a papula (solid protrusion bordered on a skin surface of }<1 \mathrm{~cm} \text { in } \\
\text { diameter) of a small needle-sized head } \\
\text { Papula grows prominent } \\
\text { The surface of the skin becomes darker and hyperkeratosis (the skin becomes thick } \\
\text { rough) } \\
\text { Itchy } \\
\text { Skin thickened }\end{array}$ & Veruca & Veruca & Suitable \\
\hline 7 & $\begin{array}{l}\text { G10 } \\
\text { G12 } \\
\text { G23 } \\
\text { G24 } \\
\text { G25 }\end{array}$ & $\begin{array}{l}\text { Itchy } \\
\text { The skin feels dry } \\
\text { Appears a red bump on the itchy part } \\
\text { Itching is more intense especially at night } \\
\text { Thickening and wrinkles on the skin are covered by yellowish-gray crust }\end{array}$ & Scabies & Scabies & Suitable \\
\hline
\end{tabular}




\begin{tabular}{|c|c|c|c|c|c|}
\hline No & & Symptoms Suffered & $\begin{array}{l}\text { System } \\
\text { Diagnostic } \\
\text { Results }\end{array}$ & $\begin{array}{l}\text { Expert } \\
\text { Diagnosis } \\
\text { Results }\end{array}$ & $\begin{array}{l}\text { Accuracy } \\
\text { of } \\
\text { Comparis } \\
\text { on } \\
\text { Results }\end{array}$ \\
\hline 8 & $\begin{array}{l}\text { G12 } \\
\text { G13 } \\
\text { G15 } \\
\text { G16 } \\
\text { G17 }\end{array}$ & $\begin{array}{l}\text { The skin feels dry } \\
\text { Skin thickened } \\
\text { The presence of macula hipopigmentasi (skin disorder where the white color is not } \\
\text { rising flat compared to surrounding healthy skin) on the asymptomatic skin } \\
\text { The appearance of white fine spots on the skin is not scaly } \\
\text { Skin looks white and slippery }\end{array}$ & Vitiligo & Vitiligo & Suitable \\
\hline 9 & $\begin{array}{l}\text { G07 } \\
\text { G08 } \\
\text { G10 } \\
\text { G23 } \\
\text { G25 }\end{array}$ & $\begin{array}{l}\text { Fever } \\
\text { Rashes appear that become small bumps then turn into nodules with fluid } \\
\text { Itchy } \\
\text { Appears a red bump on the itchy part } \\
\text { Thickening and wrinkles on the skin are covered by yellowish-gray crust }\end{array}$ & Varicella & Varicella & Suitable \\
\hline 10 & $\begin{array}{l}\text { G06 } \\
\text { G09 } \\
\text { G10 } \\
\text { G16 } \\
\text { G17 } \\
\text { G23 }\end{array}$ & $\begin{array}{l}\text { The surface of the skin becomes darker and hyperkeratosis (the skin becomes thick } \\
\text { rough) } \\
\text { Limp } \\
\text { Itchy } \\
\text { The appearance of white fine spots on the skin is not scaly } \\
\text { Skin looks white and slippery } \\
\text { Appears a red bump on the itchy part }\end{array}$ & Vitiligo & Scabies & $\begin{array}{c}\text { Not } \\
\text { Suitable }\end{array}$ \\
\hline 11 & $\begin{array}{l}\text { G01 } \\
\text { G02 } \\
\text { G03 }\end{array}$ & $\begin{array}{l}\text { Reddish patches on the skin } \\
\text { The presence of plaques (skin lesions whose surface is elevated and flat top) } \\
\text { Symptoms occur koebner phenomenon (skin disorder, where if healthy skin exposed } \\
\text { to trauma / scratched, healthy skin will also be a disorder) }\end{array}$ & Psoriasis & Psoriasis & Suitable \\
\hline 12 & $\begin{array}{l}\text { G04 } \\
\text { G05 }\end{array}$ & $\begin{array}{l}\text { Symptoms occur koebner phenomenon (skin disorder, where if healthy skin exposed } \\
\text { to trauma / scratched, healthy skin will also be a disorder) } \\
\text { The presence of a papula (solid protrusion bordered on a skin surface of }<1 \mathrm{~cm} \text { in } \\
\text { diameter) of a small needle-sized head } \\
\text { Papula grows prominent }\end{array}$ & Veruca & Veruca & Suitable \\
\hline 13 & $\begin{array}{l}\text { G07 } \\
\text { G08 } \\
\end{array}$ & $\begin{array}{l}\text { The presence of a papula (solid protrusion bordered on a skin surface of }<1 \mathrm{~cm} \text { in } \\
\text { diameter) of a small needle-sized head } \\
\text { Fever } \\
\text { Rashes appear that become small bumps then turn into nodules with fluid }\end{array}$ & Varicella & Varicella & Suitable \\
\hline 14 & $\begin{array}{l}\text { G09 } \\
\text { G10 } \\
\end{array}$ & $\begin{array}{l}\text { Rashes appear that become small bumps then turn into nodules with fluid } \\
\text { Limp } \\
\text { Itchy }\end{array}$ & Varicella & Varicella & Suitable \\
\hline 15 & $\begin{array}{l}\text { G04 } \\
\text { G06 } \\
\text { G07 }\end{array}$ & $\begin{array}{l}\text { Symptoms occur koebner phenomenon (skin disorder, where if healthy skin exposed } \\
\text { to trauma / scratched, healthy skin will also be a disorder) } \\
\text { The presence of a papula (solid protrusion bordered on a skin surface of }<1 \mathrm{~cm} \text { in } \\
\text { diameter) of a small needle-sized head } \\
\text { The surface of the skin becomes darker and hyperkeratosis (the skin becomes thick } \\
\text { rough) } \\
\text { Fever }\end{array}$ & Veruca & Veruca & Suitable \\
\hline 16 & $\begin{array}{l}\text { G10 } \\
\text { G11 } \\
\text { G12 } \\
\text { G15 }\end{array}$ & $\begin{array}{l}\text { Itchy } \\
\text { Appetite is gone } \\
\text { The skin feels dry } \\
\text { The presence of macula hipopigmentasi (skin disorder where the white color is not } \\
\text { rising flat compared to surrounding healthy skin) on the asymptomatic skin }\end{array}$ & Eczema & Eczema & Suitable \\
\hline 17 & $\begin{array}{l}\text { G09 } \\
\text { G10 } \\
\text { G21 }\end{array}$ & $\begin{array}{l}\text { Reddish patches on the skin } \\
\text { Rashes appear that become small bumps then turn into nodules with fluid } \\
\text { Limp } \\
\text { Itchy } \\
\text { The appearance of reddish spots on the skin that eventually form a bubble of liquid }\end{array}$ & Varicella & Varicella & Suitable \\
\hline 18 & $\begin{array}{l}\text { G01 } \\
\text { G10 } \\
\text { G21 }\end{array}$ & $\begin{array}{l}\text { Reddish patches on the skin } \\
\text { Itchy } \\
\text { The appearance of reddish spots on the skin that eventually form a bubble of liquid }\end{array}$ & Varicella & Varicella & Suitable \\
\hline 19 & $\begin{array}{l}\text { G10 } \\
\text { G11 } \\
\text { G18 } \\
\text { G20 } \\
\text { G22 }\end{array}$ & $\begin{array}{l}\text { Itchy } \\
\text { Appetite is gone } \\
\text { Shivering } \\
\text { Pain or joint joints in one part of the body } \\
\text { Skin blisters }\end{array}$ & Herpes & Herpes & Suitable \\
\hline 20 & $\begin{array}{l}\text { G22 } \\
\text { G23 } \\
\text { G24 } \\
\text { G25 }\end{array}$ & $\begin{array}{l}\text { Skin blisters } \\
\text { Appears a red bump on the itchy part } \\
\text { Itching is more intense especially at night } \\
\text { Thickening and wrinkles on the skin are covered by yellowish-gray crust }\end{array}$ & Scabies & Scabies & Suitable \\
\hline
\end{tabular}


From Table 11 we can calculate the accuracy value based on 20 tested data so that the percentage value obtained by $90 \%$ indicates that the accuracy of the diagnosis can work well according to the rules and the specialist skin diagnosis result so that the expert knowledge used has $90 \%$ value truth. The value of inaccuracy of $10 \%$ is likely due to errors in the assignment of the confidence of symptoms in each disease.

\section{Conclusion}

Based on the results of research and discussion it can be concluded that the automatic diagnosis of skin disease in humans requires accurate data and model rules are packed in the representation of knowledge as a basis for determining the final diagnosis. The sample simulation trials show that there is a $90 \%$ truth score that compares the diagnostic results based on expert knowledge. Value of accuracy results obtained by testing as many as 20 data samples so it can be said the accuracy obtained has a very good accuracy.

\section{References}

1. A. Djuanda, Ilmu Penyakit Kulit dan Kelamin, Ed.4. Jakarta: FKUI, (2005)
2. Siregar, Atlas Berwarna Saripati Penyakit Kulit, Jakarta: EGC, (2005)

3. Soebono, Dermatomikosis Superfisialis, Jakarta; Balai Penerbit FKUI, (2001)

4. E. G. Wahyuni, W. Prijodiprojo, IJCCS, Vol. 7, No. 2, (2013), pp. 133-144

5. R. Yager, International Joint Conference on Artificial Intelligence, (1985)

6. A. P. Dempster, Journal of the Royal Statistical Society, pp. 205-247, (1968)

7. G. Shafer, A Mathematical Theory of Evidence, Princeton University Press, New Jersey, (1976)

8. A. Maseleno, Md. M. Hasan, International Conference on Informatics for Development, pp. 9398, (2011)

9. A. Maseleno, Md. M. Hasan, International Journal of Advanced Science and Technology, Vol. 50, pp. $111-120,(2013)$

10. H. R. Hatta, F. Ulfah, D. M. Khairina, Hamdani, and S. Maharani, Journal of Theoretical and Applied Information Technology, Vol. 95, No. 11, (2017), pp. 2589-2599

11. S. Maharani, N. Dengen, G. Y. Saputra, D. M. Khairina, and H. R. Hatta, 2015 2nd International Conference on Information Technology, Computer, and Electrical Engineering ICITACEE, IEEE, pp. 87-91, (2015) 